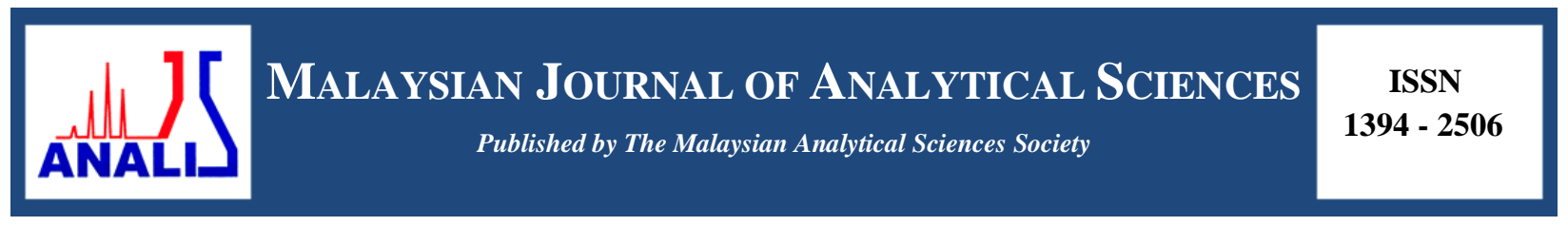

\title{
ULTRAFAST LIQUID CHROMATOGRAPHIC ESTIMATION OF SERTACONAZOLE NITRATE IN PHARMACEUTICALS USING ANALYTICAL QUALITY BY DESIGN
}

\author{
(Kromatografi Cecair Ultra-laju bagi Anggaran Sertaconazole Nitrat dalam Farmaseutikal \\ Menggunakan Reka Bentuk Kualiti Analitikal)
}

\author{
Sagar Suman Panda*, Venkata Varaha Ravi Kumar Bera, Rakeya Samanta \\ Department of Pharmaceutical Analysis and Quality Assurance, \\ Roland Institute of Pharmaceutical Sciences (Affiliated to Biju Patnaik University of Technology, Odisha), \\ Khodasingi, Berhampur-760010, Odisha, India
}

*Corresponding author: sagarguddu2002@gmail.com

Received: 24 May 2018; Accepted: 24 February 2019

\begin{abstract}
An analytical Quality by Design(AQbD) oriented ultra-fast liquid chromatography method was developed for quantification of sertaconazole nitrate in pharmaceutical dosage form. A central composite design (CCD) was employed to establish optimum chromatographic conditions ensuring method robustness by selecting methanol (\%) and flow rate (mL/min) as the factors, to study their effect on the system suitability parameters such as retention time, plate number and tailing factor as the response variable. Further, the method was carried out with design of experiments (DoE) optimized chromatographic conditions. The intermediate precision of the method was studied using a full factorial design (FFD) considering the number of days and analysts as the variables. The chromatographic separation was achieved on a phenyl-hexyl column using methanol: water (92:8, \%v/v) as the mobile phase at a flow rate of $1.3 \mathrm{~mL} / \mathrm{min}$ and photo diode array detection at $260 \mathrm{~nm}$. The values obtained for validation parameters were within the acceptance limit. The method was linear over 5-100 $\mu \mathrm{g} / \mathrm{mL}$ of sertaconazole. Analysis of the system suitability suggested a high degree of method reproducibility and robustness. In a nutshell, the method was found to be highly suitable for its applicability in the determination of sertaconazole in bulk and tablet dosage form.
\end{abstract}

Keywords: sertaconazole, ultrafast liquid chromatography, quality by design, design of experiments, robustness

\begin{abstract}
Abstrak
Reka bentuk kualiti analitikal berasaskan kaedah kromatografi cecair ultra-laju telah dibangunkan untuk pengkuantitian sertaconazole nitrat dalam bentuk dos farmaseutikal. Reka bentuk komposit berpusat (CCD) telah dibangunkan untuk mengoptimumkan keadaan kromatografi dalam memastikan keteguhan kaedahnya dengan memilih metanol (\%) dan kadar aliran $(\mathrm{mL} / \mathrm{min})$ sebagai faktor, untuk menkaji kesannya terhadap sistem kesesuaian parameter seperti masa tahanan, nombor plat dan faktor pengekoran sebagai respons pembolehubah. Selanjutnya, kaedah diuji dengan reka bentuk eksperimen (DoE) yang telah dioptimumkan. Kepersisan pengantaraan kaedah telah dikaji dengan mengunakan reka bentuk berfaktor penuh (FFD) dengan bilangan hari dan ahli analisis diambil sebagai pembolehubah. Pemisahan kromatografi telah dicapai melalui turus fenil-heksi mengunakan metanol: air $(92: 8, \% \mathrm{v} / \mathrm{v})$ sebagai fasa bergerak pada kadar aliran $1.3 \mathrm{~mL} / \mathrm{min}$ dan pengesanan susunan diod pada $260 \mathrm{~nm}$. Nilai yang diperolehi untuk parameter validasi berada had yang dibenarkan. Kaedah adalah bersifat linear dari julat 5$100 \mu \mathrm{g} / \mathrm{mL}$ sertaconazole. Analisis kesesuaian sistem mencadangkan keteguhan dan kebolehulangan kaedah adalah tinggi. Oleh demikian, kaedah yang diperolehi adalah sesuai untuk aplikasi penentuan sertaconazole di dalam dos tablet dan pukal.
\end{abstract}

Kata kunci: sertaconazole, kromatografi cecair ultra-laju, kualiti reka bentuk, reka bentuk eksperimen, keteguhan 


\section{Introduction}

Ultra-fast liquid chromatography (UFLC) is an economic and time-efficient alternative of high-performance liquid chromatography (HPLC) for fast analysis of drugs in pharmaceuticals [1-3]. This technique has diverse merits like lower mobile phase consumption, faster analysis, and high sensitivity that advocates for opting an UFLC method over HPLC for estimation of drugs in diverse samples. Sertaconazole nitrate i.e. $( \pm)-1\{2$, 4-dihydro- $\beta-[(7-$ chlorobenzo[b]thien-3-yl)-methoxy] phenethyl $\}$ imidazole nitrate (Figure 1) is an imidazole antifungal, used in treating candidiasis and seborrheic dermatitis $[4,5]$.

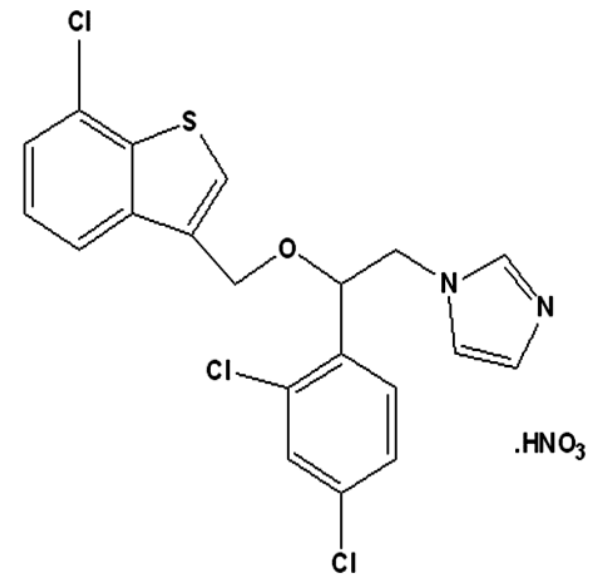

Figure 1. Chemical structure of sertaconazole nitrate

Literature reveals few chromatographic methods are reported for quantifying sertaconazole in pharmaceuticals and biological fluids, which include HPLC [6, 7] and LC-MS [8]. Lack of stability indicating nature, lower theoretical plate count, composite mobile phase, close supervisions of method parameters like mobile phase flow rate, injection volume, $\mathrm{pH}$ were the critical drawbacks found in the reported analytical methods. Moreover, there is no reported literature available describing a reliable analytical method for quantification of sertaconazole in diverse pharmaceutical samples. This calls for the development of an efficient and reliable UFLC method for estimation of sertaconazole in bulk API and pharmaceutical formulation.

Quality by Design (QbD) is a systematized holistic approach applicable to pharmaceutical development, which begins with predefined objectives and intent for accomplishing high quality in the end product and/or process [9]. Besides, it primarily facilitates rational understanding by establishing the cause-effect relationship between the quality attributes. Currently, QbD is extensively explored by analytical scientists for developing high-quality analytical methods [10-12]. QbD with respect to analytical methodology initiates with instituting the analytical target profile (ATP) and critical analytical attributes (CAAs), prioritizing followed by optimizing the critical method variables (CMVs) using an experimental design, followed by response surface analysis and desirability function to embark upon the optimal [13].

In the present research, a new UFLC method devoid of reported drawbacks was developed for quantifying sertaconazole in bulk drug and dosage form undertaking analytical QbD (AQbD) approach. A central composite design (CCD) design was adopted for systematic method optimization and establishing the optimum design space. The validation studies [14] were performed for the optimized chromatographic method. In addition, the precision of the method was ascertained by using a full factorial design (FFD). Further, the developed method was applied for the estimation of sertaconazole in tablets. 


\section{Reagents and standards}

\section{Materials and Methods}

Sertaconazole nitrate (purity $>$ 99.85\%) was obtained from Glenmark Generics Ltd., India. Methanol (Merck Ltd., Mumbai, India) was of HPLC grade. The water for HPLC was obtained by using the TKA GenPure UltraPurification System, Germany. The commercial tablet formulation containing $500 \mathrm{mg}$ of sertaconazole was procured from the local market and was analyzed by the developed method.

\section{Instrumentation and chromatographic conditions}

The UFLC system containing two Shimadzu Prominence UFLC LC-20AD pumps and SPD M20A photo diode array (PDA) detector with Shimadzu LC Solution Software was used for chromatography. Signal was recorded and integrated using Shimadzu LC Solution Software. Ultrasonicator (Enertech, India) was used during the mobile phase and sample preparation. Design of Experiments (DoE), optimization and data analysis were performed by using a trial version JMP software (SAS Institute, Inc., NC, USA) and Design Expert@ 8.0.6 Software Full Version with Serial No. 1019-4550 (Stat-Ease, Inc., Minneapolis, MN, USA).

A Phenomenex phenyl-hexyl column, $(250 \mathrm{~mm}$ x $4.6 \mathrm{~mm}$ i.d., particle size $5 \mu \mathrm{m})$ was used for separation. Chromatography was performed at room temperature using the mobile phase methanol: water (92:8, v/v) at a flow rate of $1.3 \mathrm{~mL} / \mathrm{min}$. Both methanol and water were degassed using ultrasonication up to 20 minutes followed by filtration through a $0.22 \mu \mathrm{m}$ filter.

\section{Defining ATP and CAAs}

ATP and CAAs were established based on prior literature survey and study intent. In order to meet the ATP requirement of rapid and reliable estimation of sertaconazole in tablets a UFLC technique using reversed phase was selected with sorted CAAs such as retention time, plate number, and tailing factor.

\section{Establishment of cause-effect relationship and risk management}

A typical fish- bone diagram focusing multiple method variables as causes and their effects on the CAAs of the UFLC method was drawn. Inputs from the above diagram were subjected to a failure mode and effect analysis (FMEA) study. Risk priority number (RPN) was calculated to sort out the high-risk variables affecting the CAAs. Scores were assigned to each of them for severity $(\mathrm{S})$, occurrence $(\mathrm{O})$ and detectability (D). The RPN was calculated as per equation 1:

$$
\text { Risk Priority Number }(\mathrm{RPN})=\mathrm{S} \times \mathrm{O} \times \mathrm{D}
$$

The method variables with scores more than 100 were considered as failure modes and were designated as critical method variables (CMVs) and were further subjected to systematic response surface optimization to create a robust analytical design space (DS)[15].

\section{DoE guided method development and optimization}

Two CMVs were identified, and their effect on method performance was evaluated by the DoE approach. A robust design space was established after selecting a CCD experimental domain, with the intent of obtaining fewer experiments and greater robustness. The CCD provided 10 experiments with 2 centres. In order to obtain bias-free responses, the experiments were randomized. A $10 \mu \mathrm{g} / \mathrm{mL}$ concentration of sertaconazole was tested for all the runs. The obtained data were fitted to an appropriate mathematical model by using the JMP software trial version (SAS Institute, Inc., NC, USA). Main and interaction effects among CMVs were studied using the developed model. Exhaustive data analysis based on multiple linear regression analysis (MLRA) was performed by evaluating the actual versus predicted plot, fit summary analysis, analysis of variance (ANOVA), lack of fit, the coefficient of correlation $\left(\mathrm{R}^{2}\right)$, adjusted and predicted $\mathrm{R}^{2}$, predicted residual sum of squares (PRESS). Model aptness was decided by evaluating prediction expression, prediction profiler, interaction profiler; 2-D contour plot and 3-D response surface profiler. 


\section{Method control strategy}

Method control strategies were defined based upon the results obtained for various system suitability parameters viz. retention time, plate number and tailing factor during the study days. $\bar{X}-S$ control chart was prepared for CMVs using Minitab ${ }^{\circledR}$ Software (Minitab Inc.) to monitor the instrument performance over a period of six days with three injections per day. The obtained observations were evaluated with respect to the mean $(\bar{X})$, mean of standard deviation $(\bar{S})$, LCL (lower control limit) and UCL (upper control limit). The information derived from control charts were used effectively to define the control strategy through the operable limits for CMVs.

\section{Preparation of standard stock solution}

Approximately $25 \mathrm{mg}$ of sertaconazole was transferred into a $25 \mathrm{~mL}$ volumetric flask having $10 \mathrm{~mL}$ of methanol and ultrasonicated for 5 minutes. Finally, the volume was made up with methanol to produce $1000 \mu \mathrm{g} / \mathrm{mL}$ standard stock solution of sertaconazole. Calibration solutions were prepared from this solution at concentrations of 5-100 $\mu \mathrm{g} / \mathrm{mL}$ of sertaconazole using mobile phase. Each calibration standard solution was injected in triplicates, chromatograms were obtained and mean peak areas were calculated. The linear calibration curve was drawn taking concentration $(\mu \mathrm{g} / \mathrm{mL})$ on the $\mathrm{x}$-axis and the peak area on the $\mathrm{y}$-axis. Regression analysis (including ANOVA) of calibration data was performed to detect the regression statistics.

\section{Analysis of tablet dosage form}

Tablet powder equivalent to $25 \mathrm{mg}$ of sertaconazole was ultrasonicated for 20 minutes in a $25 \mathrm{~mL}$ volumetric flask, containing methanol. Volume was made up followed by filtration through a $0.45 \mu \mathrm{m}$ filter. Further, the filtered solution was diluted for analysis, to obtain a test concentration within the linear range. These solutions were stored at $2-8^{\circ} \mathrm{C}$ for up to 6 days.

\section{Validation studies: Accuracy}

Recovery studies were performed in triplicate at $80 \%(16 \mu \mathrm{g} / \mathrm{mL}), 100 \%(20 \mu \mathrm{g} / \mathrm{mL})$ and $120 \%(24 \mu \mathrm{g} / \mathrm{mL})$ of the test concentration of sertaconazole. Drug present in the test solution was calculated using the calibration curve.

\section{Precision}

The precision study was performed in terms of system, inter- and intra-day. Six injections of a selected concentration of drug were carried out to determine the system precision. The intraday precision was found out using the peak area acquired by analyzing six solutions of a fixed amount of sertaconazole.

Inter-day precision of the method was studied using a full factorial design (FFD). Number of days (A) and analyst (B) were the two factors, and the peak area was the response chosen for the study. Total of 16 experimental runs was suggested by FFD using Design Expert ${ }^{\circledR}$ 8.0.6 Software Full Version with Serial No. 1019-4550 (Stat-Ease, Inc., Minneapolis, MN, USA). All the experimental runs were performed in randomized order to obtain results without any bias. Various effect tools, diagnostic plots, and model graphs were studied to find out critical method parameters affecting response. A solution of concentration $20 \mu \mathrm{g} / \mathrm{mL}$ of sertaconazole was analyzed by UFLC and percent relative standard deviations (\%RSD) were calculated.

\section{Limit of Detection (LOD) \& Limit of Quantitation(LOQ)}

Signal to Noise $(\mathrm{S} / \mathrm{N})$ ratio of $3: 1$ and 10:1 were considered vital for visual detection of LOD and LOQ, respectively.

\section{Specificity and selectivity}

Specificity was evaluated by inspecting the possible interference from the placebo. The commonly used additives (hydroxypropylmethyl cellulose, microcrystalline cellulose, magnesium stearate and talc) were incorporated into the standard solutions and were analyzed. Method selectivity was ensured by recovery and analysis of the analyte in presence of formulation components. 


\section{Method development studies}

\section{Results and Discussion}

Based on prior knowledge and physicochemical properties of the analyte the initial chromatographic trials were conducted. Various chromatographic parameters, including mobile phase composition and ratio, stationary phase, mobile phase flow rates. were investigated to find the desired response. A Phenomenex phenyl-hexyl column was used for separation of the compound as it provides superior selectivity, high inertness with least tailing, resistance to extreme $\mathrm{pH}$ conditions, higher stability to aqueous mobile phases than compared to $\mathrm{C}_{18}$. Various preliminary experimental trials were conducted at ambient temperature using different mobile phase compositions like methanol: water, methanol: buffer $(\mathrm{pH} 6.8)$, methanol: buffer $\mathrm{pH} 7.0$ at varying ratios (i.e., 50:50, 60:40, 70:30, $80: 20,85: 15,90: 10,92: 8, \mathrm{v} / \mathrm{v})$ and flow rates $(0.8,1.0,1.2$ and $1.3 \mathrm{~mL} / \mathrm{min})$. Methanol: water $(92: 8, \mathrm{v} / \mathrm{v})$ at a flow rate of $1.3 \mathrm{~mL} / \mathrm{min}$ produced a symmetrical peak at retention time of $6.2 \mathrm{~min}$ with PDA detection at $260 \mathrm{~nm}$. Further, to study the factors affecting the separation of sertaconazole and to optimize the method robustness, AQbD approach was implemented.

\section{Cause-and-effect based risk assessment and its management}

Evaluation of the Ishikawa fish-bone diagram (Figure 2) revealed the primary causes and secondary sub-causes, which are responsible for the variability and alteration in method performance.

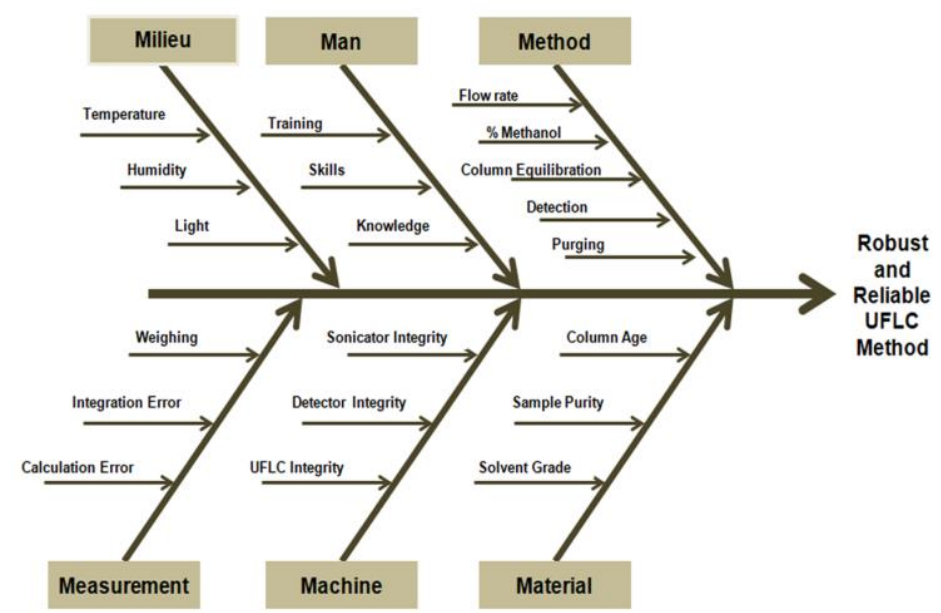

Figure 2. Typical fish-bone diagram depicting the cause and effect relationship between method variables and method performance

To carry out an effective risk assessment, for the present studies, the FMEA approach with RPN was utilized (Table 1). The CMVs were identified based on the final score followed by response surface optimization to create the DS for developing a robust and reliable UFLC method. 
$\begin{array}{ll}\text { Panda et al: } & \text { ULTRAFAST LIQUID CHROMATOGRAPHIC ESTIMATION OF SERTACONAZOLE NITRATE } \\ \text { IN PHARMACEUTICALS USING ANALYTICAL QUALITY BY DESIGN }\end{array}$

Table 1. Various failure modes studied during FMEA study

\begin{tabular}{llcccc}
\hline Mode of Failure & Effect & S & O & D & RPN Score \\
\hline Solvent grade & Extra peaks & 3 & 3 & 3 & 27 \\
Flow rate & Multiple & 5 & 5 & 7 & 175 \\
Column age & Non-selectivity & 4 & 3 & 2 & 24 \\
Methanol \% & Multiple & 6 & 5 & 6 & 180 \\
Sample purity & Extra peaks & 2 & 3 & 2 & 12 \\
Column equilibration & Extra peaks & 3 & 3 & 3 & 27 \\
Detection & Varying peak profile & 2 & 2 & 2 & 8 \\
Purging & Pressure variation & 3 & 2 & 3 & 18 \\
\hline
\end{tabular}

AQbD based chromatographic method optimization

Based on the risk assessment studies, two CMVs were identified with significant influence on the method performance. Percentage methanol and mobile phase flow rate were subjected to further studies to assess the method robustness. Ten experimental runs (Table 2) obtained as per CCD model were performed on a random basis using UFLC and responses were obtained to ensure method robustness for identifying optimized chromatographic conditions.

Table 2. Range of chromatographic variables studied as per experimental design

\begin{tabular}{lcc}
\hline Run Number & Methanol \% & Flow rate (mL/min) \\
\hline 1 & 90 & 1.4 \\
2 & 92 & 1.4 \\
3 & 92 & 1.3 \\
4 & 92 & 1.2 \\
5 & 90 & 1.2 \\
6 & 90 & 1.3 \\
7 & 94 & 1.3 \\
8 & 92 & 1.3 \\
9 & 94 & 1.2 \\
10 & 94 & 1.4 \\
Levels Studied & Methanol \% & Flow rate (mL/min) \\
Low & 90 & 1.2 \\
Nominal & 92 & 1.3 \\
High & 94 & 1.4 \\
\hline
\end{tabular}

\section{Optimization data analysis}

The obtained data for each experimental run were fitted to a suitable mathematical model by MLRA using JMP software (SAS Institute, Inc., NC, USA). The developed model was allowed to study both the main effects and interaction effects among the CMVs studied.

After obtaining the responses suitable mathematical models were adopted. Prediction expression as polynomial equations (Eq.2-4) containing model terms for both main effects and interaction effects were generated for all the 
three responses. It explains the relationship between the CMVs and CAAs and predicts the CAAs values within the levels of CMVs studied.

$$
\begin{aligned}
& \text { Retention Time }= \begin{array}{l}
6.2846429+[-1.009667 \times \text { Methanol }]+[-0.482667 \times \text { Flow rate }]+[0.47825 \times(\text { Methanol } \times \text { Flow } \\
\text { rate })]+[0.1442143 \times(\text { Methanol } \times \text { Methanol })]+[0.5112143 \times(\text { Flow rate } \times \text { Flow rate })(2)
\end{array} \\
& \text { Plate Number }=\begin{array}{l}
7608.5357+[117.18333 \times \text { Methanol }]+[-1010.333 \times \text { Flow rate }]+[624.025 \times(\text { Methanol } \times \text { Flow } \\
\text { rate })]+[-3328.671 \times(\text { Methanol } \times \text { Flow rate })]+[83.278571 \times(\text { Flow rate } \times \text { Flow rate })(3)
\end{array} \\
& \text { Tailing factor }=\begin{array}{l}
1.4722143+[-0.028667 \times \text { Methanol }]+[-0.077167 \times \text { Flow rate }]+[-0.00125 \times(\text { Methanol } \times \text { Flow } \\
\text { rate })]+[-346929 \times(\text { Methanol } \times \text { Methanol })]+[0.0205714 \times(\text { Flow rate } \times \text { Flow rate })(4)
\end{array}
\end{aligned}
$$

Evaluation of ANOVA was carried out for model fitness and significant difference $(p<0.05)$ along with values of $R^{2}$ $\left(\mathrm{R}^{2}>0.9\right)$ were obtained. All these statistical parameters confirmed the suitability of the selected mathematical model for predicting the responses. Interaction effect analysis was carried out using interaction profilers. The plots (not shown in figures) for interaction suggested a non-linear pattern among the CMVs on the CAAs studied. High degree of interactions among both the CMVs was obtained for the CAA plate number, as the factor lines were intersecting each other. This intersection of factor lines indicated a potential cause for possible variability in plate count, which demands strict control measures to be undertaken.

Response surface analysis was carried out employing 2-D contour and 3-D plots (Figure 3- (a-d)). Figure 3(a) demonstrates the overall design space developed through 2-D contours. Figure 3(b) indicates maximal values of retention time at low levels of methanol \% and flow rate. A typical "ridge" system was observed for both the CMVs for plate number and tailing factor. On the other hand, high plate number was observed at mid levels of methanol \% and at low to mid levels of flow rate (Figure 3(c)). Optimum tailing values were obtained at mid levels of methanol $\%$ and at low to mid levels of flow rate (Figure 3(d)).

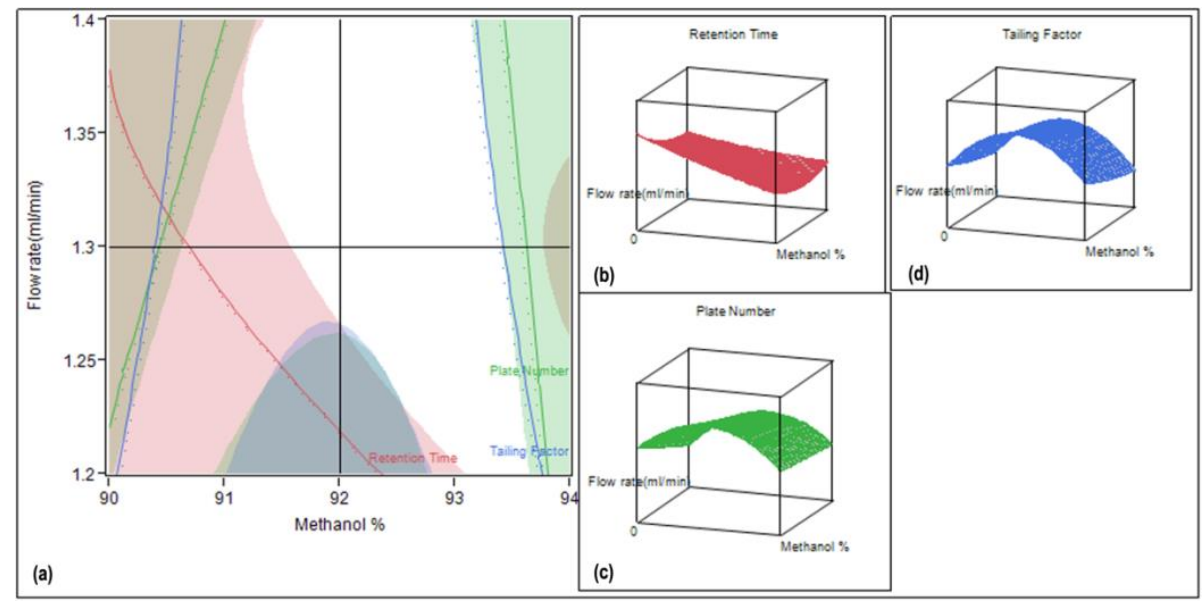

Figure 3. 2-D contour (a) and 3-D response surface (b, c, d) plots obtained for CAAs

The desirability plot along with prediction profiler (Figure 4) suggested optimum chromatographic conditions for the CAAs such as retention time, plate number and tailing factor. Further, the method was carried out with DoE optimized chromatographic conditions, which resulted in superior method robustness and efficient system suitability values compared to the reported HPLC method for sertaconazole [7]. The reported method proposed poor theoretical plate count of 1153 which is well below the standard minimum plate count by the USP (>2000) [16]. 
Panda et al: ULTRAFAST LIQUID CHROMATOGRAPHIC ESTIMATION OF SERTACONAZOLE NITRATE IN PHARMACEUTICALS USING ANALYTICAL QUALITY BY DESIGN

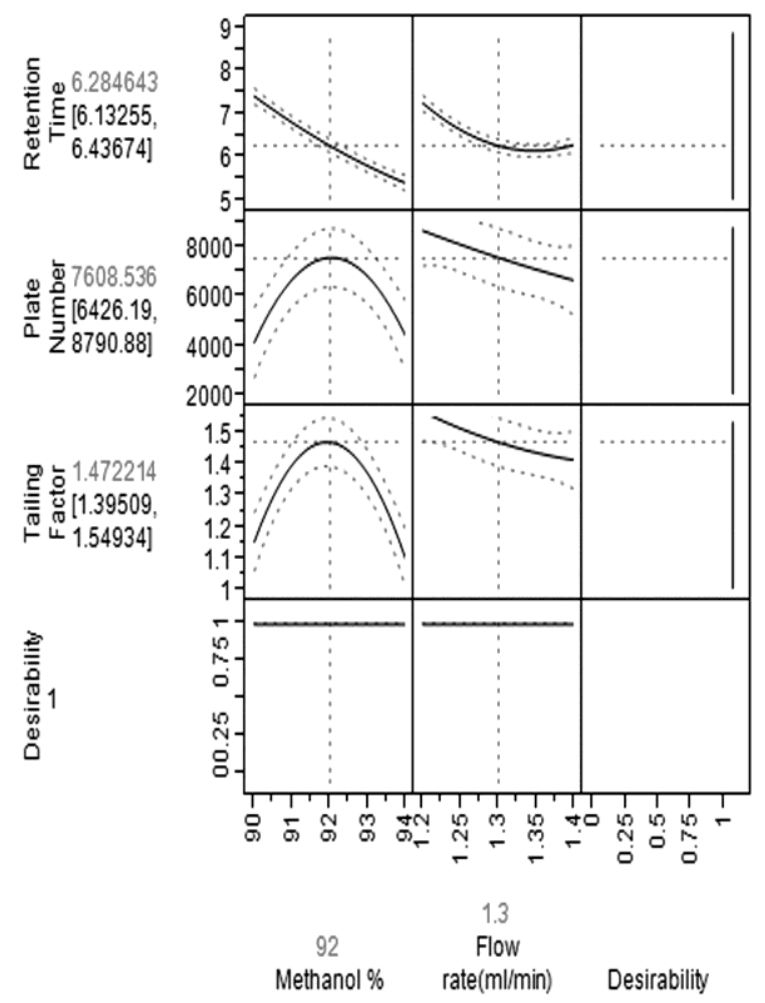

Figure 4. Prediction profiler along with desirability plot obtained for CAAs viz. retention time, plate number and tailing factor
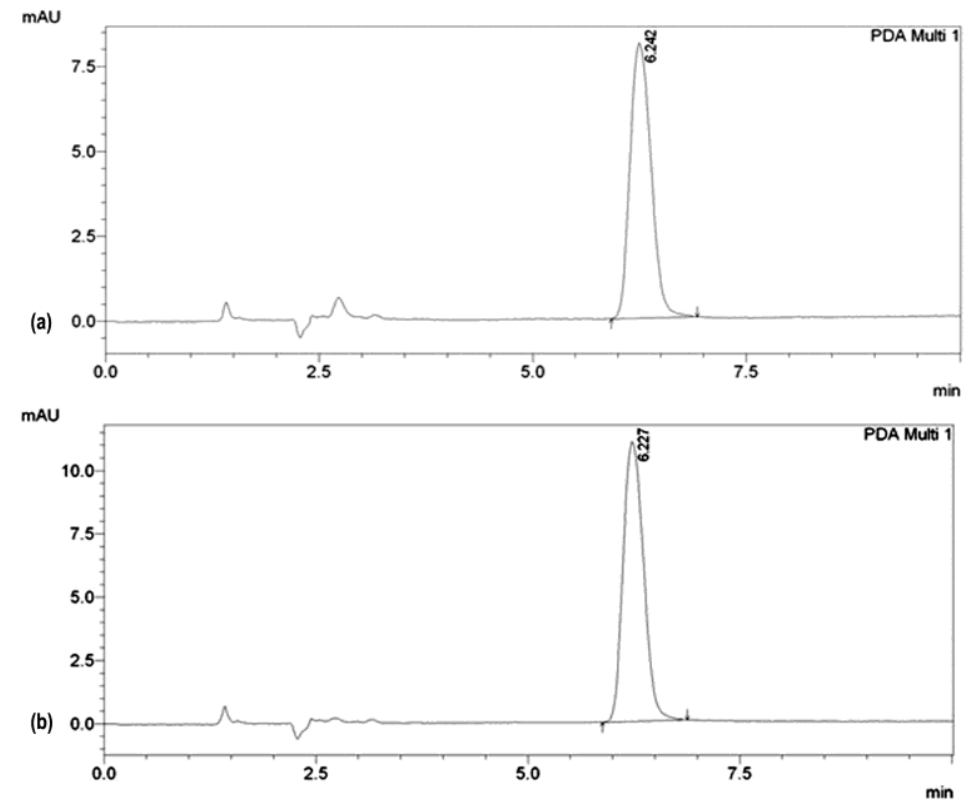

Figure 5. Typical representative chromatograms of sertaconazole in (a) standard drug and (b) tablet dosage form 


\section{Validation studies: Linearity}

A linear calibration curve was obtained for sertaconazole within the concentrations of $5-100 \mu \mathrm{g} / \mathrm{mL}\left(\mathrm{R}^{2}=0.999\right)$, which is much wider than the reported HPLC method [7]. The result of the regression analysis of linearity data suggested goodness of fit. The values obtained for statistical parameters such as multiple $R, R^{2}$, adjusted $R^{2}$ and standard error were $0.9995,0.999,0.9988$ and 12756.45 , respectively.

\section{Accuracy}

The results of recovery revealed (Table 3) a high degree of accuracy of the method. Average recoveries of drug ranging between 99.55 and $99.99 \%$, for spiked concentrations, 16, 20 and $24 \mu \mathrm{g} / \mathrm{mL}$, were obtained.

Table 3. Results of accuracy study

\begin{tabular}{lcc}
\hline $\begin{array}{l}\text { Level Studied } \\
(\%)\end{array}$ & $\begin{array}{c}\text { Spiked Concentration } \\
(\boldsymbol{\mu g} / \mathbf{m L})\end{array}$ & $\begin{array}{l}\text { Recovery* } \\
(\%) \pm \text { S.D. }\end{array}$ \\
\hline 80 & 16 & $99.58 \pm 1.7$ \\
100 & 20 & $99.99 \pm 1.0$ \\
120 & 24 & $99.55 \pm 0.9$ \\
\hline
\end{tabular}

*Mean of three separate determinations

\section{Precision}

The $\%$ RSD for system and intraday precision was found to be 0.13 and 0.57 , respectively. In the case of inter-day precision, the overall \% RSD was found to be 0.45 using experimental design approaches.

Table 4. Experimental design matrix for inter-day precision

\begin{tabular}{llc}
\hline Run No. & Number of Day & Analysts \\
\hline 1 & Day 1 & 2 \\
2 & Day 2 & 1 \\
3 & Day 2 & 2 \\
4 & Day 1 & 1 \\
5 & Day 2 & 1 \\
6 & Day 2 & 2 \\
7 & Day 2 & 1 \\
8 & Day 1 & 2 \\
9 & Day 2 & 1 \\
10 & Day 1 & 2 \\
11 & Day 2 & 2 \\
12 & Day 1 & 1 \\
13 & Day 1 & 1 \\
14 & Day 2 & 2 \\
15 & Day 1 & 2 \\
16 & Day 1 & 1 \\
\hline
\end{tabular}


Application of an FFD (Table 4) ensured the screening of method factors, which can significantly affect the precision. An overall study of different effect tools, diagnostic plots, model graphs and response plots (Figure 6-a-d) revealed the number of days of the study was the most critical factor affecting the intermediate precision of the method.

(a)

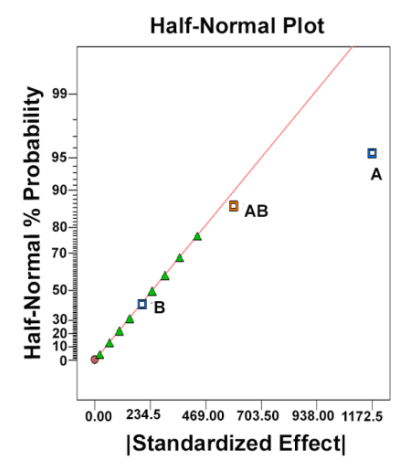

(c)

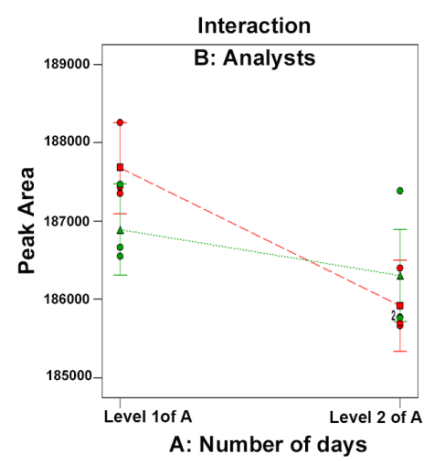

(b)

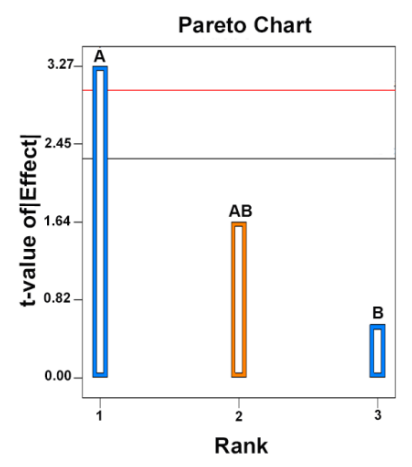

(d)

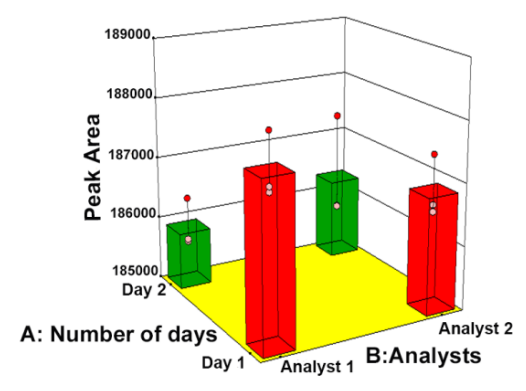

Figure 6. Effect tools, diagnostic plots and model graphs obtained for intermediate precision using experimental design; (a): Half-normal plot, (b): Pareto chart, (c): Interaction plot and (d):3-D surface plot

Further, the superior preciseness of the present method was confirmed by comparing the \%RSD values obtained for the present method with that of the reported ones (Table 5).

Table 5. Comparison of \% R.S.D. values obtained for the precision studies of the present method with the reported method

\begin{tabular}{lcccc}
\hline Precision Type & \multicolumn{4}{c}{ \%R.S.D. } \\
\hline & $\begin{array}{c}\text { Reported Method } \\
\text { for Cream [6] }\end{array}$ & $\begin{array}{c}\text { Reported Method } \\
\text { for Solution [7] }\end{array}$ & $\begin{array}{c}\text { Reported Method } \\
\text { for Powder [7] }\end{array}$ & $\begin{array}{c}\text { Present Method } \\
\text { for Tablet }\end{array}$ \\
Intra-day & 1.72 & 0.9 & 0.6 & 0.57 \\
Inter-day & 2.17 & 0.6 & 0.5 & 0.45 \\
\hline
\end{tabular}

\section{Solution stability}

The result of solution stability showed no significant degradation or change in sertaconazole content. The average $(\mathrm{n}=3)$ recoveries were $99.22 \%(\mathrm{RSD}=0.2 \%)$ and $98.86 \%(\mathrm{RSD}=0.33 \%)$, for Days 1 and 2, respectively. The results suggest that drug solutions were stable up to two days under refrigeration. 


\section{Limit of detection (LOD) and limit of quantitation (LOQ)}

The reported method [7] has a LOD and LOQ value of 1.24 and $3.78 \mu \mathrm{g} / \mathrm{mL}$, respectively using a cyano column employing a complex mobile phase consisting of $0.1 \mathrm{M}$ sodium dodecyl sulphate, $20 \%$ 1-propanol, and $0.3 \%$ triethylamine in $0.02 \mathrm{M}$ ortho-phosphoric acid $(\mathrm{pH} 4)$. However, the present LOD and LOQ values were found to be 3.25 and $5.0 \mu \mathrm{g} / \mathrm{mL}$, respectively using a phenyl-hexyl column employing methanol and water, and are well in accordance with the linearity concentrations studied.

\section{Method control strategy}

The system suitability results obtained during control runs indicated (Figure 7) a robust and optimum instrument performance within the DS for the most influential CMVs such as methanol proportion $( \pm 2 \%)$ and flow rate $( \pm 0.1 \mathrm{~mL} / \mathrm{min})$.

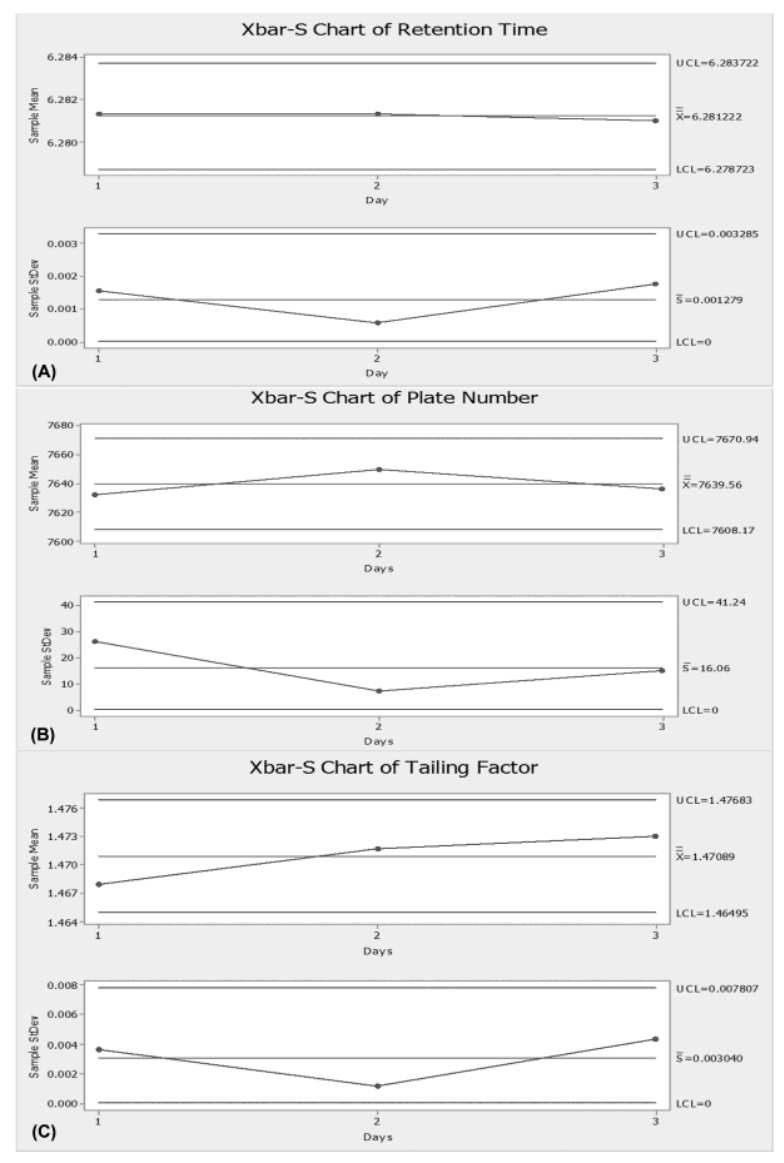

Figure 7. Control chart depicting method performance on different days of study

\section{Specificity and selectivity}

Study of a chromatogram obtained for placebo demonstrated no interference due to the commonly used excipients, which suggested method specificity. Further, method selectivity was ascertained by comparing the chromatograms of placebo (Figure 8) and drug in tablet dosage form (Figure 5 (b)).

\section{Assay of tablet dosage form}

The developed method was applied for the estimation of sertaconazole in the tablet dosage form. The result of the assay $(n=3)$ for the drug yielded $99.19 \%(S D=0.75)$ of sertaconazole. Comparison of assay results (Table 6) with 
that of the reported HPLC method using $t$-test indicated the aptness of the sample extraction procedure from the tablet dosage form. The comparison revealed that the calculated value of $t$ was greater than tabulated one indicating a significant difference between the results of the reported and present method for quantifying sertaconazole in tablets and solution form. Contrary to the above observed the $t$-value was found well within the tabulated value indicating no significant difference among the results of the reported and present method for estimation of sertaconazole in powder and tablet dosage form, respectively. The higher percentage of recovery and noninterference of the formulation excipients in the estimation of the drug indicates the selectivity of the method. A typical chromatogram of the commonly used excipients and additives in the tablet dosage form depicted noninterference at analyte retention at $6.2 \mathrm{~min}$ (Figure 8). Further, the results vowed the befitting nature of the AQbD approach for the present chromatographic studies.

Table 6. Comparison of results obtained for dosage form analysis by the reported method and the present method

\begin{tabular}{lcccc}
\hline Method & Formulation Type & Recovery* $(\%)$, S.D. & \multicolumn{2}{c}{ t-value $(\mathbf{p}=\mathbf{0 . 0 5} ; \mathbf{d f} * *=4)$} \\
\cline { 4 - 5 } & & & Tabulated & Observed \\
\hline \multirow{2}{*}{ Reported [7] } & Solution & $97.0,1.0$ & 2.78 & 3.034 \\
& Powder & $98.4,1.2$ & 2.78 & 1.03 \\
Present & Tablet & $99.19,0.75$ & & \\
\hline
\end{tabular}

*Mean of three separate determinations, $* * \mathrm{df}=$ Degrees of freedom

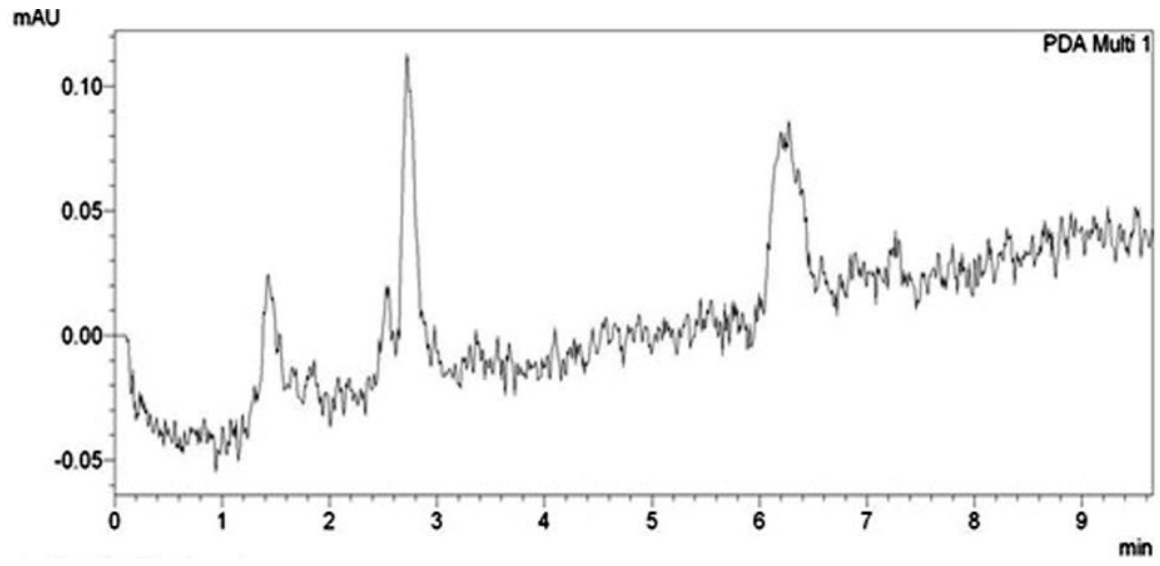

Figure 8. Typical chromatogram depicting non-interference of excipients and additives in analytes retention time

\section{Conclusion}

A reliable and robust reverse phase UFLC method was developed for the estimation of sertaconazole. Implementation of $\mathrm{AQbD}$ approach ensured that quality is built into the analytical method instead of testing. Use of methanol instead of acetonitrile as organic phase efficiently removed the toxicity issues related to the mobile phase. Validation studies according to ICH guidance presented satisfactory and acceptable results. Employing the DoE approach to an intermediate precision study revealed the effect of factors that may influence method preciseness over days of an experiment by a different analyst. The results obtained from the above studies indicate that this method is well suited for routine analysis of sertaconazole in bulk drug and pharmaceutical dosage forms. Further, this systematically optimized robust chromatographic method has the potential for future continuous improvement in method performance through strict monitoring of CAAs and may serve as a basis for optimizing the analytical method for sertaconazole present in biological samples for pharmacokinetics studies. 


\section{Acknowledgements}

The authors are thankful to Glenmark Pharmaceuticals Ltd., India for providing the gift sample of sertaconazole nitrate standard drug and Roland Institute of Pharmaceutical Sciences, Berhampur-10, Odisha, India for providing the research facilities.

\section{References}

1. Panda, S. S., Bera, V. V. R. K., Mohanta, G. and Patel, P. K. (2012). New stability indicating RP-UFLC method for determination of trospium chloride in tablet dosage form. Scientia Pharmaceutica, 80: 955 - 964.

2. Panda, S. S., Bera, V. V. R. K., Mohanta, G. and Panda, J. (2013). Reverse phase ultrafast liquid chromatography method for simultaneous estimation of citicoline sodium and piracetam in tablets. International Journal of Pharmaceutical Sceicnes and Nanotechnology, 6(1): 1952 - 1957.

3. Panda, S. S., Bera, V. V. R. K., Mohanta, G. and Kumari, A. (2015). Ultrafast liquid chromatographic determination of naproxen sodium in pharmaceutical dosage form. American Journal of Modern Chromatography, 2(2): $16-25$.

4. Carrillo-Munoz, A. J., Tur-Tur, C., Giusiano, G., Marcos-Arias, C., Eraso, E., Jauregizar, N. and Quindos, G. (2013). Sertaconazole: An antifungal agent for the topical treatment of superficial candidiasis. Expert Review of Anti-Infective Therapy, 11(4): 347 - 358.

5. Goldust, M., Rezaee, E. and Raghifar, R. (2013). Treatment of seborrheic dermatitis, comparison of sertaconazole 2\% cream versus ketoconazole 2\% cream. Irish Journal of Medical Science, 182(4): 703 - 706.

6. Albert, C., Fernandez, J. M., Rozman, E., Perez, J. A., Sacristan, A. and Ortiz, J. A. (1992). Determination of sertaconazole nitrate, a new imidazole antifungal, by high-performance liquid chromatography. Journal of Pharmaceutical and Biomedical Analysis, 10(2-3): 205 - 211.

7. Risk, M., Toubar, S. S., El-Alamin, M. M. A. and Azab, M. M. M. (2014). Micellar liquid chromatographic determination of sertaconazole and terconazole in bulk, pharmaceutical dosage forms and spiked human plasma. Bulletin Faculty of Pharmacy, Cairo University, 52(1): 155 - 164.

8. Wang, Y., Pang, L., Wu, M. and Ou, N. (2009) A validated LC-MS/MS method for determination of sertaconazole nitrate in human plasma. Journal of Chromatography B, 877(31): 4047 - 4050.

9. Pharmaceutical Development Q8. (2009), ICH Harmonized Tripartite Guideline: pp. 1 - 24.

10. Panda, S. S., Bera, V. V. R. K., Beg, S. and Sahu, S. K. (2015). Ultrafast liquid chromatographic method development and its validation for quantification of telaprevir in pharmaceutical dosage form by using quality by design approach. Journal of Chromatographic Science, 53(7): 1193 - 1202.

11. Panda, S. S., Beg, S., Bera, V. V. R. K. and Singh, P. (2015). Analytical quality-by-design compliant ultrafast liquid chromatographic method for determination of paliperidone in extended release tablet dosage form. Journal of Bioanalysis \& Biomedicine, 7: 116 - 123.

12. Beg, S., Sharma, G., Katare, O. P., Lohan, S. and Singh, B. (2015). Development and validation of a stabilityindicating liquid chromatographic method for estimating olmesartan medoxomil using quality by design. Journal of Chromatographic Science , 53(7): 1048 - 1059.

13. Lionberger, R. A., Lee, S. L., Lee, L. M., Raw, A. and Yu, L. W. (2008). Quality by design: concepts for ANDAs. The AAPS Journal, 10(2): $268-276$.

14. Validation of analytical procedures: Text and methodology, ICH harmonized tripartite guideline, (2005). Access from https://www.ich.org/fileadmin/Public_Web_Site/ICH_Products/Guidelines/Quality/Q2_R1/Step4/ Q2_R1_Guideline.pdf [Accessed online 11 February 2018].

15. McDermott, R. E., Mikulak, R. J. B. (2008) The basics of FMEA. CRC Press, Taylor \& Francis Group, New York.

16. United States Pharmacopoeia 40 ${ }^{\text {th }}$ ed. (2017); The United States Pharmacopeia Convention, Rockville, MD. 